University of Wollongong

Research Online

Faculty of Law, Humanities and the Arts Papers (Archive)

Faculty of Arts, Social Sciences \& Humanities

$1-1-2011$

The transcolonial politics of Chinese domestic mastery in Singapore and Darwin 1910s-1930s

Claire K. Lowrie

University of Newcastle, clowrie@uow.edu.au

Follow this and additional works at: https://ro.uow.edu.au/lhapapers

Part of the Arts and Humanities Commons, and the Law Commons

Research Online is the open access institutional repository for the University of Wollongong. For further information contact the UOW Library: research-pubs@uow.edu.au 


\title{
The transcolonial politics of Chinese domestic mastery in Singapore and Darwin 1910s-1930s
}

\begin{abstract}
Feminist and postcolonial scholars have long argued that the home was a microcosm and a symbol of the colony. To exercise power in the home, to practice domestic mastery over colonised servants, was an expression of colonial power. At the same time, intimate contact and domestic conflicts between nonwhite servants and their employers had the potential to destabilise hierarchical distinctions, thereby threatening the stability of colonial rule. As Ann Laura Stoler puts it, the home was a site where "racial classifications were defined and defied" and where relations between coloniser and colonised could sustain or challenge colonial rule. The vast majority of the literature on the colonial home focuses on European homes and the domestic service relationship as one between a white master/mistress and a native servant. The 2007 special issue of Frontiers, for example, focuses on white-"native" encounters. Yet, in many colonial contexts, Asian and Indigenous elites employed domestic servants in their homes. As Swapna Banerjee has shown in her study of Bengal in British India, the relationship of "subordination" in colonial societies was not unique to "white masters/mistresses and native/black servants" but crossed class and ethnic lines.

This paper rethinks understandings of colonial power and intimacy by analysing domestic service in Chinese homes in the neighbouring tropical British colonies of Singapore, in the Straits Settlements, and Darwin, in Australia's Northern Territory, from the 1910s to the 1930s. A comparison of this sort might, at first glance, seem implausible. Singapore was an exploitation colony where the aim was to extract labour and produce. Darwin, on the other hand, was part of a settler colony where the intended outcome of colonialism was permanent white settlement based on the dispossession of the Indigenous populations. The different colonial objectives in Singapore and Darwin became more obvious following the federation of Australia in 1901, at which point Darwin became part of a settler nation rather than a British colony. However, as Penny Edwards and Deana Heath have shown, the process of analysing settler and nonsettler colonies side-by-side enables historians to draw broader conclusions about colonialism itself. In this case, such a comparison highlights the extent to which the position of coloniser was ambiguous, bound up with issues of race and class, and dependent on colonial context.
\end{abstract}

\section{Keywords}

mastery, transcolonial, politics, chinese, singapore, darwin, domestic, 1930s, 1910s

\section{Disciplines}

Arts and Humanities | Law

\section{Publication Details}

Lowrie, C. K. (2011). The transcolonial politics of Chinese domestic mastery in Singapore and Darwin 1910s-1930s. Journal of Colonialism and Colonial History, 12 (3), 1-24. 
The Transcolonial Politics of Chinese Domestic Mastery in Singapore and Darwin 1910s-1930s

Claire Lowrie

University of Newcastle, Australia1

Introduction

Feminist and postcolonial scholars have long argued that the home was a microcosm and a symbol of the colony. To exercise power in the home, to practice domestic mastery over colonised servants, was an expression of colonial power. At the same time, intimate contact and domestic conflicts between non-white servants and their employers had the potential to destabilise hierarchical distinctions, thereby threatening the stability of colonial rule.2 As Ann Laura Stoler puts it, the home was a site where "racial classifications were defined and defied" and where relations between coloniser and colonised could sustain or challenge colonial rule. 3 The vast majority of the literature on the colonial home focuses on European homes and the domestic service relationship as one between a white master/mistress and a native servant.4 The 2007 special issue of Frontiers, for example, focuses on white-"native" encounters.5 Yet, in many colonial contexts, Asian and Indigenous elites employed domestic servants in their homes.6 As Swapna Banerjee has shown in her study of Bengal in British India, the relationship of "subordination" in colonial societies was not unique to "white masters/mistresses and native/black servants" but crossed class and ethnic lines.7

This paper rethinks understandings of colonial power and intimacy by analysing domestic service in Chinese homes in the neighbouring tropical British colonies of Singapore, in the Straits Settlements, and Darwin, in Australia's Northern Territory, from the 1910s to the 1930s. A comparison of this sort might, at first glance, seem implausible. Singapore was an exploitation colony where the aim was to extract labour and produce. Darwin, on the other hand, was part of a settler colony where the intended outcome of colonialism was permanent white settlement based on the dispossession of the Indigenous populations. 8 The different colonial objectives in Singapore and Darwin became more obvious following the federation of Australia in 1901, at which point Darwin became part of a settler nation rather than a British colony. However, as Penny Edwards and Deana Heath have shown, the process of analysing settler and non-settler colonies side-by-side enables historians to draw broader conclusions about colonialism itself.9 In this case, such a comparison highlights the extent to which the position of coloniser was ambiguous, bound up with issues of race and class, and dependent on colonial context.

Stoler's work on "poor whites" and mixed-descent individuals in the Dutch East Indies has shown how the distinctions between coloniser and colonised changed over time and depended not only race but also on "a critical class-based logic." 10 The ambiguous position of non-European elites in the colonial scheme of things is just as striking. As Kam Louie has argued, far from being "victims" of colonialism, Chinese communities exercised colonial power in their own right.11 In Singapore, elite members of the China-born and Chinese descended communities collaborated with the British to keep the majority population in check.12 In Darwin, while the Chinese experienced racial discrimination at the hands of the colonial government, in many ways they behaved as colonisers themselves, seeking, as Penny Edwards and Shen Yuanfang write, "to accumulate wealth and land."13 As one contributor to the Northern Territory Times put it, the Chinese did not behave as colonial subjects but as "Mongolian colonists."14 
The colonial significance of domestic mastery ensured that the capacity of the Chinese to employ Chinese and non-Chinese servants in their homes was seen as further evidence of their ambiguous place in the colonial hierarchy. In Singapore, illustrations of Chinese mastery had long been admired and celebrated by British colonisers. In Darwin, by contrast, the British and Australian-born residents resolutely condemned Chinese domestic mastery. The distinct reactions of white colonists in Singapore and Darwin reflected the structural differences between settler and exploitation colonialism. In Singapore, the ability to extract profits relied on the social stability provided by elite Chinese. Thus, illustrations of Chinese wealth and power were seen to solidify British colonial rule. Although Darwin was a multi-ethnic town on the edge of Asia, it was nonetheless situated within a white settler nation. Here demonstrations of Chinese power were viewed as a direct threat to white power and thus to the colonial venture itself.

The different attitudes toward Chinese mastery came to the fore during the "child rescue" campaigns that circulated across the colonial world in the 1920s and 1930s. In both Singapore and Darwin, calls for child rescue promoted governmental intervention into Chinese homes. In Darwin, the Commonwealth government administration pursued this "civilising mission" with enthusiasm, banning the Chinese from employing Aboriginal servants and, in particular, mixed-descent girls. The white residents of Darwin condemned the Chinese as corrupt masters and contrasted them with the (supposedly) kindly white mistresses who employed Aboriginal domestics in their homes. By denying the Chinese the ability to practice domestic mastery and by condemning them as corrupt both the government and the public could be assured that that the only genuine and moral colonists were white colonists.

In Singapore, the Straits Settlements government intervened in Chinese affairs reluctantly; superficial legislative changes were adopted which ensured that mui tsai (girl slaves) employed in Chinese homes at least appeared to be free. Here, British colonists, even those directly involved in rescuing mui tsai, were reluctant to condemn the Chinese as corrupt masters. The fact that the British in Singapore couched the resolution of the mui tsai problem in terms of child rescue but were reluctant to draw the inevitable conclusion that the Chinese were corrupting masters (and that the British were by contrast always civilising and good) allowed the British to avoid long-term responsibility for Singapore and left open the possibility that respectable middle and upper class Chinese were capable of colonial mastery.

An analysis of Chinese homes in Singapore and Darwin illustrates the importance of considering the politics of intimacy and colonial power outside of European homes. Public debate about who was an appropriate domestic master, anxiety about Chinese employers of servants, and governmental interference in Chinese domestic affairs indicates the validity of analysing these homes as key sites of colonial power. Considering Chinese domestic mastery in a settler and an exploitation colony highlights the centrality not only of categories of race but also those of class in determining coloniser status. In Singapore, class power was central to coloniser status while in Darwin distinctions of race were far more important.

The article begins by examining how a common culture of domestic service developed in Singapore and Darwin and how Chinese employers of servants fitted into this culture. The impact of the child rescue movement on Chinese homes will then be analysed with a focus on the hesitation of colonial authorities to intervene in Chinese homes in Singapore versus the enthusiasm with which 
intervention was pursued in Darwin. The final section of the paper explores how Chinese employers were depicted in government documents, newspapers articles, humanitarian reports, memoirs and fiction produced by British and Australian colonists. I show how in Singapore, Chinese masters were depicted in sympathetic terms while in Darwin they were condemned. My central argument is that the different ways child rescue played out in these sites and the different ways Chinese employers were represented related to the colonial significance of domestic mastery and the contrasting ambitions of settler and exploitation colonialism.

\section{Colonial Cultures of Domestic Service in Singapore and Darwin}

Singapore and Darwin may have been marked by their different status as exploitation versus settler colonies, but there were key similarities between the two sites. Both were established as British colonial ports designed to take advantage of the trade routes through Asia to Europe. Singapore was, however, far more successful in this regard.15 The two colonies were united by a shared tropical climate and similar multiethnic populations, which included a Chinese majority and a much smaller European population. In addition to these commonalities, the two sites have a history of connection and interaction. Like other colonial port cities, Darwin and Singapore acted as "crossroads" or "contact zones" where goods, ideas, cultures and people from the surrounding regions mixed and mingled.16 Their connections were forged through steam ships, particularly the Burns Philp Line that dominated the route to Singapore, Java, Darwin, Thursday Island, Brisbane and Sydney, via the Torres Strait.17 These connections and commonalties resulted in the cultivation of a similar tropical colonial culture. Indeed, the white elites of Darwin actively embraced a lifestyle that mirrored that of the British in Singapore, donning white plantation suits and solar topees (pith helmets), and employing a multiethnic entourage of domestic servants, including Chinese "houseboys."

Darwin, at the northern tip of Australia, was a multi-ethnic society with a small white population. In the whole of the Northern Territory in 1910, the 1,200-strong European population was dwarfed by 3,300 "immigrants" and an estimated 10,000 to 50,000 Aboriginal people. The vast majority of immigrants were from China and the dialect groups included Sze Yap, Heung-san and Hakka.18 The Chinese community consisted of a small number of businessmen and merchants and a large number of labourers. Elite Chinese mixed in European social circles in Darwin and had some influence in the community.19 Other immigrant groups represented in the town included Japanese, Filipinos, Timorese and "Malays" from other parts of the Indonesian archipelago.20

The numbers of Chinese in the Northern Territory peaked in 1888 when they outnumbered the white population by four to one.21 Though "coloured" labour had long been viewed as essential in the tropical northern Australian climate, white colonists, particularly British and Australian businessmen and entrepreneurs, were keen to limit Chinese power and influence in the colony. The large numbers of Chinese in the Northern Territory was thus cause for concern. In response, in 1888 the government introduced a poll tax targeting Asian immigrants. Policies of immigration restriction were stepped up following the introduction of the white Australia policy in 1901, the cornerstone of which was the Immigration Restriction Act.22 In 1911 when the Commonwealth government took over the administration of the Northern Territory from South Australia, immigration restriction was combined with polices of economic discrimination that sought to replace Chinese with white workers. Such policies ensured that many labouring class Chinese either headed south in search of 
work or returned to China. For those who could not afford to go home, the Commonwealth government covered the cost of a passage to Hong Kong. 23

Despite government efforts, in 1911 the Chinese still outnumbered the white population, making up thirty-two per cent of Darwin's 1,387 residents compared with a white population of twenty-six per cent (most of whom were British-born or Australian-born of British extraction).24 Even in 1938, Darwin's Chinese population stood at twenty-five per cent but, unlike previous eras when the majority of the community was of labouring class origin, the population was largely Australian-born and middle class. A significant number were also Australian citizens having been naturalised in the years before it was outlawed under section five of the Commonwealth Naturalization Act of 1903. In a country supposedly founded on white colonisation, the status of Darwin's Chinese residents as Australia-born settlers was a worrying anomaly.

The population of Darwin was dwarfed by that of the Singapore, which stood at over three hundred thousand in 1911. Nonetheless, like Darwin, Singapore's community consisted of a Chinese majority, a smaller European population and a mix of other Asian communities, including Malays, Indians, Arabs and Eurasians. The European population made up a mere two per cent of the population in 1911 and was mostly of British extraction. The Chinese majority reached sixty-six per cent in 1891 and stabilised at seventy-five per cent in 1911.25 It was a community divided by dialect, clan, class and citizenship. Hokkiens were the most prominent group in Singapore, followed by Teochews, Cantonese, Hakkas and (at the bottom of the social ladder) Hainanese.26 In terms of class, the population consisted of merchants (shang), educated elite (shih) and labourers (kung.)27 The Chinese community was also divided by citizenship. The Peranakan or Straits Chinese had resided in Southeast Asia's port cities for centuries and had married into local Malay communities. The elite of the Straits Chinese community spoke English and were British subjects loyal to the crown.28 The huaqiao (overseas Chinese) were the larger group in Singapore and were Chinese citizens.29

The British approach to managing the Chinese population in Singapore was very different to that in Darwin. Rather than seeking to confine the Chinese to a subordinate position (and ultimately to exclude them altogether), the British in Singapore fostered ethnic and class divisions in order to cultivate a close relationship with Chinese elites. From the early colonial days, the Chinese towkays (merchants) and the educated elite of the Straits Chinese community played a role in government. The Chinese were able to advise the administration, sit on semi-governmental committees, or work in the public service. By using the elites as "collaborators," the British sought to keep the Chinese majority in check.30

In terms of the cultural traditions of domestic service, British and white Australian colonists in Singapore and Darwin, along with European colonists in other tropical colonies, considered the presence of multiple servants in the home essential to managing the ravages of the climate. 31 The ability to employ large numbers of so-called "coloured" servants was also a viewed as a symbol of the power of white colonisers and it was a very necessary indication of power in tropical colonies where Europeans were often a minority population.32 In both Singapore and Darwin the domestic servant population was large (compared with the colonial metropoles of England and south-eastern Australia), multi-ethnic and male-dominated.33 In Singapore, all British colonists were able to employ Chinese, Indian or Malay servants, regardless of their class position. As the editor of the Straits Times, John Cameron, put it in 1865: "even the ordinary style of living in Singapore may be set 
down as luxurious" by the standards of "home."34 The white residents of Darwin also enjoyed the presence of Chinese, Malay and Aboriginal servants, although the numbers of servants was smaller than in Singapore. Thus, Charlotte Urquhart, wife of the administrator of the Northern Territory, Frederic Urquhart, explained in 1926 that Darwin was "like the East without the East's comforts."35 Nonetheless, the presence of servants in all white homes in Darwin was in distinct contrast to the southeastern areas of Australia such as New South Wales, where in 1901 only nine per cent of the population employed any servants at all.36

White colonists were not the only ones who employed domestic labour. Recalling his childhood in a wealthy Hokkien household in Singapore in the 1910s, Low Cheng Gin explained that the family lived in what "the English called the aristocratic way" surrounded by numerous servants. 37 In Singapore, Chinese (particularly from the Hainanese community) and Malay men were employed in Chinese homes. In addition, from the 1920s, as the numbers of Chinese female migrants in the colony rose, domestic servants called amahs were increasingly used. A significant number of these women were maijie or "black and white amahs" who were members of spinster sisterhoods. Mui tsai (girl slaves) were also widely employed in Chinese homes.38 In Darwin, the Chinese community employed Aboriginal men to work in their homes and businesses. In some cases, mixed-descent girls were also employed as nursemaids to Chinese children.39

The response of white colonists to Chinese domestic mastery in Darwin was in distinct contrast to Singapore. While facilitating the arrival of Chinese labourers in the Northern Territory in the 1870s, mining entrepreneur John Lewis suggested that the Chinese "should come simply to work for Europeans and be servants... they must be treated as a subject race." $40 \mathrm{~A}$ contributor to the local newspaper agreed, maintaining that while Chinese could be employed for "any menial task... the concession should stop there." 41 In Darwin, the Chinese were to be servants and subordinates rather than masters of servants and colonists. In Singapore, Chinese wealth and power was admired rather than feared. Thus, in 1839 Howard Malcolm, an American missionary in Singapore, maintained that the numerous servants in Chinese homes "testified the high claim of the Chinese to the character of a civilized people."42 C.D. Mackellar, a British visitor to Singapore in 1901, saw it in similar terms, claiming to "admire" the "fat, rich-looking Chinese" with his Malay servants.43

The different responses of white colonists to the elite Chinese in Darwin and Singapore reflected the very different trajectories of the two colonies. The intention for Darwin was that it would one day be a member of a white settler nation. Evidence of Chinese wealth and influence, particularly in the context of a significant Australian-born Chinese population, was highly problematic. In contrast, Singapore was intended to remain an exploitation colony, a site from which profits could be shipped back to the metropole. Here, the wealth and influence of Chinese elites, in the context of a majority Chinese population, stabilised a colonial order based on distinctions of race and class. The different attitudes towards Chinese domestic mastery in Darwin and Singapore came to the fore during the transcolonial child rescue movement of the interwar years.

The Politics of Child Rescue in Chinese Homes

The period following World War I marked a time of humanitarian critique in the colonial world. Feminists, Christians and philanthropists condemned what they saw as systemic slavery and exploitation, and actively lobbied colonial governments to protect the welfare of colonised subjects, especially women and children. One key manifestation of this climate of humanitarianism is what 
Shurlee Swain has referred to as the "transcolonial child rescue movement."44 In sites as diverse as Australia, the Dutch East Indies, North America, French Indochina and British Burma, notions of rescuing children from "inadequate parenting" or the "corrupting influence" of class and racial "others" justified the removal of children from their homes or places of work. The traditions of child rescue drew on campaigns that targeted working class children in Britain during the nineteenth century. The rescued children were institutionalised at the behest of colonial governments and educated to a level considered consistent with class and racial categories. In all cases, new ideas about white women's domesticating, civilising and maternal capabilities ensured that they were allocated an active role in child rescue. 45

In Darwin and Singapore, calls for child rescue and the government intervention that resulted targeted domestic servants employed in Chinese homes. In both sites, colonial administrators were implored to rescue servants from conditions of slavery, physical and sexual abuse and opium addiction. In Singapore, these kinds of claims emerged in response to the mui tsai practice. In Darwin, claims of corruption were directed at Chinese employers of Aboriginal people, particularly mixed-descent girls. By adopting the child rescue platform, the governments of Singapore and Darwin were able to uphold a public image of moral legitimacy at a time of intense criticism. The results of the interventions were, however, very different, reflecting the distinct colonial objectives of exploitation and settler colonialism.

In Singapore claims of slavery resulted in the Straits Settlements government regulating and eventually prohibiting the mui tsai system. The mui tsai practice was an established Chinese tradition that involved poor families in southern China and parts of Malaya selling their daughters into servitude. Significant numbers of these girls ended up working for Chinese families in Hong Kong, Malaya and Singapore.46 In 1922, it was estimated that between seven thousand and ten thousand mui tsai were working in Chinese homes in Singapore. In her 1937 "Minority Report," activist and government representative, Edith Picton-Tubervill maintained, "every Chinese household that could afford to had a mui tsai."47 A test sample of one hundred mui tsai in 1930 showed that most worked in the homes of Teochew shopkeepers. They ranged in age from 6 to thirteen, and on reaching puberty, the girls were married off or became concubines. 48

The mui tsai system had been subject to criticism as early as the turn of the century. By the 1920s, the occasional criticisms had turned into an international humanitarian campaign, prominent in Asia, Britain, the United States and Australia. International organisations, including the League of Nations slavery committees, the British Aborigines Protection League and various missionary organisations in China labelled the practice child slavery and called for its abolition.49 Within the Chinese community, there were differing opinions about the status of mui tsai. Some Chinese elites in Hong Kong, Singapore and Malaya certainly maintained that the mui tsai were slaves and sought to abolish the system. Others, however, defended the practice. As early as 1898, unofficial legislative council member, Lim Boom Keng (under the pen name Lin Meng Cheng), argued in Singapore's wellrespected Straits Chinese Magazine that becoming a mui tsai saved Chinese girls from lives of poverty and misery in China and that for the most part they were well treated.50 These kinds of arguments were repeated in the 1920s and 1930s with elite Chinese families in Singapore and Hong Kong maintaining that the mui tsai were more like "adopted daughter[s]" or "sisters" than "slaves."51 The different opinions amongst the Chinese community are not surprising considering the diversity of the population. 
In Singapore, and in Hong Kong where the mui tsai debate first emerged, colonial authorities were reluctant to intervene in Chinese domestic affairs. In the context of a Chinese majority that was partly kept in check through collaboration with Chinese elites, outright condemnation and intervention into Chinese domestic affairs risked destabilising the colony. Accusations of slavery, however, could not be ignored. Since abolition in 1833, opposition to slavery had afforded British "moral superiority," and evidence of slavery operating in British colonies, in Eric Tagliacozzo's words, "made a mockery of the ostensible civilising mission."52 Hong Kong's South China Morning Post highlighted the connection between the mui tsai system and the reputation of British imperial rule in 1930: "It is absolutely necessary that we should be freed from the accusation of slavery. As a British colony it is unthinkable that we should continue the system as at present." 53 The best way for officials to maintain a position of moral superiority and colonial legitimacy was to embrace the child rescue platform.

The first piece of legislation which sought to regulate the mui tsai practice in Singapore was the 1925 Female Domestic Servants Law which was designed, according to the "Protector" of Chinese, Victor Purcell, "to safeguard the moral and material interests of Chinese girls" by making it an offence to employ a mui tsai less than 10 years of age. The law was, however, completely ineffective as it was impossible to determine the exact age of the child.54 The Straits Settlements government made a more serious attempt to intervene in the mui tsai system with the 1933 Mui Tsai Ordinance, which was administered by the Chinese Protectorate. The ordinance demanded the registration of all existing mui tsai, the payment of a small wage of 1 to 3 dollars per month, and regular inspections of their working conditions. Mui tsai who were considered to be in danger of abuse could be removed from their employer's home and sent to the Po Leung Kuk, a refuge opened in 1878.55

The Chinese Protectorate's European lady inspectors, shadowed by Chinese assistant protectors, were charged with the task of visiting Chinese homes where they knew mui tsai to be employed. True to the civilising role they were entrusted with in other colonial contexts, these women were depicted as substitute mothers to the mui tsai and at least some white women saw themselves in this light.56 This perception of their role was no doubt enhanced by the knowledge that the mui tsai had been given up by their biological mothers. In Singapore, former mui tsai Janet Lim recalled that a European lady inspector, Mrs. Winter, visited her workplace and told her "to let her know if we were badly treated." Lim continued: "she told us to think of her as a mother."57 To Lim's profound disappointment, however, this did not mean that Mrs. Winter would take her home and treat her as a daughter. Instead, after running away from her employer, Lim was sent to the Po Leung Kuk.

The Po Leung Kuk was used to rehabilitate and "civilise" mui tsai who had been removed from their employers or who had run away. It was hoped training in domestic work would help the girls find suitable employment as domestic servants in upper and middle class Chinese and European homes and ultimately make them into respectable women worthy of marriage. 58 The reports from the Po Leung Kuk are testament to the idealised process of transformation: "Of the three admitted to the Po Leung Kuk one was reported by her employer as unmanageable... She was admitted... in January and by October had won the Mabel Winter Shield for good conduct. Soon afterwards employment was found for her as a domestic servant in a respectable family."59 Further action was taken with the commissioning of a report on the mui tsai in 1937. The "Majority Report" argued that, as most mui tsai now worked for their employers as free servants and were generally well cared for, outright removal of all mui tsai was unnecessary. However, in contrast to the "Majority Report," Picton- 
Turbervill's "Minority Report" maintained that the system and its abuses were ongoing and urged further action. The government took action with the Straits Settlements Children's Ordinance of 1938-1940. However, the outbreak of World War II ensured it was never instituted.60

The public condemnation of the mui tsai practice and growing governmental interference made the prospect of employing mui tsai inconvenient and played a part in the growing popularity of free Chinese amahs from the late 1920s.61 However, neither the Domestic Service Law (1925) nor the Mui Tsai Ordinance (1933) ended mui tsai practice. Instead, the laws drove the system underground, with owners disguising their mui tsai as family members or simply refusing to register them -the favoured response of Lucy Lum's grandmother in Singapore in the 1930s.62 Even when Chinese employers followed the regulations and paid the required wage, the payment for the work was set at far below the minimum wage.63 In any case, as Purcell later admitted, the intention of the 1933 ordinance was not to end the mui tsai practice but to protect the reputation of the empire by resolving the accusation of slavery operating in the colony.64 Setting a compulsory monthly wage ensured that mui tsai at least appeared to be free domestic workers.

The government approach to the mui tsai sought to recreate the nineteenth century British tradition of domestic apprenticeship whereby working class families sent their children into service as a means of ensuring they were fed and clothed. The middle and upper class recipients of these child servants not only derived benefit from their service but took comfort in the belief that they were civilising working class families and destitute children.65 The influence of these English ideas can be seen in an editorial in Hong Kong's South China Morning Post where it was suggested that a means of overcoming the exploitation of mui tsai lay in dropping the name and cultivating an attitude toward the girl as a "sort of daughter" and a "servant in training."66

By making superficial changes to transform the system into a form of domestic apprenticeship, the Straits Settlements government sought to silence claims of slavery while avoiding offending the elite Chinese on whom colonial power in part rested. By recasting the image of the girl slave into a domestic apprentice, by mobilising white women as protectors and by creating a place of rehabilitation, the Straits Settlements government presented itself as an agent of child rescue. But while in Singapore the government intervention into Chinese homes was tokenistic, in Darwin it was pursued enthusiastically.

The Commonwealth government takeover of the Northern Territory in 1911 saw the implementation of policies designed to incorporate the northern frontier into the white Australian nation.67 The multiethnic north presented a major challenge to "white" Australia. Immigration restrictions allowed the government to curtail nonwhite settlement, but the Indigenous populations, though increasingly displaced from their traditional lands, remained at the fringes of settler society. Government officials comforted themselves with the belief that "full-blood" Aboriginal people were a "dying race," but they could not dismiss the growing mixed-descent population so easily. In the early years of Port Darwin or Palmerston, as it was originally called, white, Asian and Aboriginal communities were able to mix with relative freedom and as a result, an ethnically mixed population developed. The "half-caste problem" was widely accepted as a major obstacle to the achievement of a white Australia.68

In Darwin, the Commonwealth government sought to deal with this "problem" through child removal and racial segregation. Aboriginal children considered to be of a "pale shade" were 
removed from their families and communities. The mixed-descent boys were trained as manual labourers, often as stock workers, while most girls were recruited as domestic servants for white families.69 At the same time, Aboriginal people were banned from Chinatown; schools were segregated according to race and so-called "Asiatics" were banned from employing Aboriginal people.70 Such policies were pursued under the guise of Aboriginal protection and child rescue.

The South Australian government's Aborigines Act of 1910 first banned the Chinese community in Darwin from employing Aboriginal servants. The act put in place a system of protectors headed by a chief protector who was responsible for the movements, employment and wages of Aboriginal people. Aboriginal reserves were established and the chief protector was invested with the power to remove Aboriginal people there. Potential white employers had to apply for an annual license to employ Aboriginal workers, while the Chinese were barred from receiving a license. The Aborigines Act was modelled on Queensland's 1901 amendment to the Aboriginals Protection and Restriction of the Sale of Opium Act (1897) and Western Australia's Aborigines Act of 1905. In all cases, the key concern was to stem interracial contact by prohibiting Asians (especially the Chinese) from employing Aboriginal people and cohabiting with them.71

The 1910 Act was reinforced in the 1911 Aboriginals Ordinance, passed under the Commonwealth administration. The Commonwealth instituted another Aboriginals Ordinance in 1918, which formalised the system of removal of children, targeting mixed-descent females in particular, and attempted to regulate the conditions of their employment within white homes.72 As with the 1911 version, it stipulated that: "No licence to employ aboriginals shall be granted to any male person of any Asiatic race." In later years, the Chinese were given approval to employ Aboriginal men but were still prohibited from employing Aboriginal and mixed-descent women and girls. This illustrates that fears of miscegenation remained.73

Even before the passing of the 1910 act and the ordinances of 1911 and 1918, the children of Chinese fathers and Aboriginal mothers were targeted for removal as a matter of policy. This was also the case in neighbouring Queensland, where the children of Chinese and Aboriginal parents were automatically regarded as ill cared for.74 Such attitudes are resonant with those of colonial administrators in the Dutch East Indies where the refusal of native mothers to give up their mixeddescent children was portrayed as an act of neglect.75 Aboriginal servants in Chinese homes were also targeted for removal before the official legislation was passed. This was especially the case if the servant in question was a mixed-descent girl.

In 1898 the inspector of police and protector of aborigines, Paul Foelsche called for the removal of a mixed-descent girl, Polly, from the home of Harry Sue Lee where she was employed as a nursemaid. Lee's status as a merchant gave him the confidence to question the decision and prompted the government to make enquiries. However, Lee's class status did not ensure a favourable outcome. The claim that Polly was in a relationship with one of Lee's Chinese employees was seen to justify her removal from the home and her recruitment into service for the government. 76 The targeting of mixed-descent girls for removal was by no means unusual in colonial societies. In British Burma and French Indochina notions of "rescuing" mixed-descent girls from their dangerous environments, the "cultural affiliations of their native mothers" and their perceived potential for promiscuity were common and often resulted in child removal.77 
The Chinese community responded to this overt discrimination by petitioning the administrator of the Northern Territory and the Commonwealth minister for external affairs in 1911 and again in 1912. Seven Chinese storekeepers and tradesmen pleaded with the government in 1911: "Many of us have had blackboys in our employ for years and have always treated them well and the boys do not want to leave us. This will work [sic] great hardship on us." They pointed out that most of the community had lived in Darwin for many years and made an important contribution to the economy.78 In 1912, eleven Chinese businessmen reiterated their concerns through a second petition and provided examples of the forced closure of Chinese businesses due to the loss of Aboriginal labour.79 Their complaints failed to move a government deeply committed to achieving a white Australia through racial segregation.

The anthropologist Baldwin Spencer was appointed chief protector of Aboriginals by the Commonwealth administration in 1912. Following Spencer's report and recommendations, Aboriginal people from Darwin and the surrounding regions were confined to the Kahlin Compound, which was opened in 1913. There was a separate fenced compound called the Kahlin Half-Caste Girls Home where mixed-descent girls were sent. As with the Po Leung Kuk in Singapore, Kahlin Half-Caste Girls Home was seen as a place where they could be uplifted. Thus, Hilda Muir was told she was in Kahlin "to be civilised." 80 The ultimate ambition in the Kahlin Half-Caste home was to create women worthy of marriage or servitude in respectable homes. This ambition was one shared with Singapore's Po Leung Kuk. However, in the Po Leung Kuk the aim was merely the achievement of middle class respectability while in Darwin the intention was one of assimilating mixed-descent Aboriginal girls into white society in an effort to "effect the disappearance of the race."81

The differences in the desired outcomes of child rescue in Singapore and Darwin are striking. They can be understood in the context of the distinct aims of exploitation and settler colonialism. Comparing child rescue in North America to the Dutch East Indies, Stoler argues that the intention of achieving white settlement in America (rather than merely extracting labour and produce) ensured that the removal, institutionalisation and schooling of Native American girls was designed "to obliterate an entire culture." 82 In Darwin by the 1930s, child rescue targeting mixed-descent girls was directed at eugenic assimilation. C.E. Cook, chief protector of Aboriginals and chief medical officer in the Northern Territory from 1927, was a particular champion of this approach. While Spencer had advocated mere segregation for the mixed-descent community, Cook's ambition was that mixed-descent girls in service would marry working class white men and ultimately breed out colour.83

In Singapore, the child rescue movement ensured that some mui tsai were removed from conditions of slavery. In Darwin, the same rhetoric resulted in mixed-descent children being systematically removed from their families, communities or places of employment and forced to work in white homes. In theory, Aboriginal girls in Darwin received some remuneration for their work as domestics in white homes. However, it was held in a government trust, did not reflect the hours of labour performed and they often never received the money at all.84 Similarly to Singapore, government officials framed this system of virtual slavery as a domestic apprenticeship. As Victoria Haskins puts it, the nineteenth century methods of dealing with girls from the "dangerous classes" in England by forcing the children of the poor into domestic "apprenticeship" for which they received little or no wage were adapted to "solve" the Aboriginal "problem." 85 All the Australian states implemented the forcible removal of Aboriginal children with this in view.86 
In contrast to Singapore, in Darwin humanitarian criticism generally focused on the increased government interventions into the lives of colonised people rather than the lack of it. Within Australia, direct criticism of the policies of Aboriginal protection was rare but not completely unheard of. Mary Montgomery Bennett, a feminist and mission teacher from Western Australia, described the conditions of Aboriginal employment in white homes as "analogous to slavery" and criticised the policy of removing Aboriginal children from their families and communities.87 The media in Britain and Europe agreed, labelling the licensing system that controlled the use of Aboriginal labour, as one of "slave certificates."88

Even those who supported the policy of Aboriginal child removal, such as the Women's Non-Party Association of South Australia, expressed concerns about the sexual vulnerability of Aboriginal girls in white homes and called for the appointment of female inspectors.89 In lobbying for female inspectors, these groups were drawing on traditions in other British colonies, such as Singapore, where female inspectors were appointed to protect the mui tsai in Chinese homes. Not surprisingly, the Australian authorities resisted such requests. As Fiona Paisley has explained, to employ female protectors to inspect white homes was to admit that: "white men were the problem on the frontier." In the Northern Territory, the government was much more inclined to blame the sexual abuse of Aboriginal girls on Chinese men and the supposedly "lustful half-caste females" themselves.90

In Darwin (unlike Singapore) the humanitarian criticisms did little to alter government policy. While claims of exploitation of Aboriginal people caused some embarrassment and discomfort on the international stage, the government was more concerned with the future white nation. The decision to ban the Chinese from employing Aboriginal labour was part of a broader policy of segregation designed to stem to the growing numbers of mixed-descent individuals in order to turn the multiethic north into a member of the white Australian community. The fact that the government had mobilised the rhetoric and practices of child rescue from the very beginning of its intervention meant that it was resilient to the criticisms of humanitarians and was able to respond to the protests of groups, such as the Chinese, by claiming a moral high ground.

It was not just governmental intervention into Chinese homes that played out in different ways in Darwin and Singapore. In memoirs, newspaper articles, government documents and humanitarian reports, upper and middle class white colonists in these sites depicted the Chinese in very different ways. The distinct colonial representations in the two sites related to the political significance of domestic mastery and reflected the different role the Chinese were allocated in colonial Darwin and Singapore.

British and White Australian Reponses to Chinese Mastery: Corrupting or kindly?

At the heart of the child rescue rhetoric was the notion of the long-term corrupting effects of bad influences. As it was Chinese homes that were targeted for intervention, the implication was that the Chinese were corrupting masters. In Singapore, even humanitarians working to rescue mui tsai were reluctant to condemn the Chinese as corrupt masters. In contrast, in Darwin the discourse of the corrupting Chinese master was mobilised with conviction and contrasted with its "natural" opposite-the kindly white mistress. The discourse of the corrupting Chinese master (not to mention the kindly white mistress) had very little to do with what actually went on within colonial homes. Indeed, both the mui tsai employed in Chinese homes in Singapore and the mixed-descent girls 
employed in white homes in Darwin, considered themselves slaves. For European colonisers, to be a good and worthy domestic master was to be a good and worthy coloniser. Thus, to accept that the Chinese could be good domestic masters was to infer that they had the potential to be legitimate colonisers. In Singapore, the British were (relatively) willing to accept that upper and middle class Chinese were capable of colonial mastery while in Darwin the white community could not accept such a possibility.

The image of the corrupting Chinese master had a history in both Singapore and Darwin. In both sites, white colonists expressed concerns about Chinese employers who were addicted to opium, practiced slavery and assaulted their servants, physically as well as sexually. In Hugh Clifford's 1913 Malayan short story "Two Little Slave Girls," for example, Malay sisters escape a Chinese master and flee to "the white folk" to be liberated from "slavery, for the white man will not suffer it."91 By rejecting slavery and rescuing the children, Clifford asserted that the British in Malaya were moral and worthy rulers. When it came to the mui tsai controversy, however, the Straits Settlements government and its representatives were hesitant to mobilise this discourse. Unlike Clifford's Malayan story, the claim of protecting an Indigenous population from the exploitation of colonial migrants was not a factor. There were different issues at stake.

This is not to suggest that the discourse of the corrupting Chinese master did not circulate in the colony at all. As Susan Pederson argues in Hong Kong, in the eyes of many white feminists, Chinese men could not help but enslave young girls and as a result public debate focused on the abuse (particularly sexual abuse) of mui tsai by Chinese men. Likewise, Sarah Paddle discusses western feminist ideas about the "immoral Chinese man" buying and selling girls in China.92 There is also evidence that such concerns played out in Singapore. In her 1937 "Minority Report," PictonTurbervill argued that the sexual abuse of mui tsai was common due to the notions of ownership that ensured that "the purchaser" feels "he has a possession with which he can do as he pleases."93 While the government in Singapore may not have publically admitted it, the perceived need for female inspectors to protect mui tsai in Chinese homes also alludes to such fears.

Chinese masters might have been more prevalent in the public debate about sexual abuse, but Chinese mistresses also came under criticism. In both Singapore and Hong Kong stories of "callous mistress[es]" violently abusing mui tsai featured in the local European newspapers.94 In general, however, the response of the British was measured, especially considering the exploitive nature of the mui tsai system and the fact that in other contexts (such as Darwin) the Chinese were condemned for far lesser actions.

The British in Singapore were swayed by the arguments made by Chinese employers that the mui tsai were treated as family members rather than slaves and were rarely abused. Thus, Victor Purcell accepted that "the mui tsai was a member of the family whereas a paid domestic servant was not" and that as a result mui tsai were better off and rarely subjected to abuse.95 Even those involved in the rescue of mui tsai demonstrated cultural sensitivity in their depiction of Chinese masters. Lucia Bach, who was involved in the care of abused mui tsai in the 1920s and 1930s, maintained that "very often" becoming a mui tsai gave Chinese girls "a better chance in life."96 In her "Minority Report," Picton-Turbervill conceded: "there has been in England a tendency to exaggerate the extent of the evil... on the whole the community is law-abiding."97 What these humanitarian and government perspectives have in common is a measured, thoughtful and (relatively) culturally sensitive approach 
to the mui tsai question. They do not mobilise the discourse of the corrupting Chinese master to condemn the entire Chinese population.

While government representatives might have comforted themselves with the notion that mui tsai were family members rather than slaves, the mui tsai themselves remember their experience unequivocally as a case of slavery. Janet Lim, for example, forcefully recounts her experience in Singapore: "It is very difficult for people to understand what it means to be a slave, to be bargained for and sold like merchandise, to suffer shame and the whips of one's master and mistress." 98 In any case, as studies of both contemporary and historical domestic service have shown, the idea of domestic workers as "part of the family" does not ensure favourable treatment.99 Notions of ownership based on family ties or slavery gave employers unparalleled power over mui tsai. Some mui tsai were well treated. Nonetheless, abuse and exploitation certainly took place. PictonTurbervill was quite right in maintaining that it was the system that was the problem.100

As Paddle has argued, the cultural sensitivity displayed by the British in Asia can be understood in the context of a western feminist movement that was increasingly "internationalist and racially aware."101 For the colonial government in Singapore, however, the display of cultural sensitivity also had a practical purpose. The reluctance of the British to employ the discourse of the corrupting Chinese master, despite the evidence of abuse, needs to be read in the context of a majority Chinese population and a Chinese elite with close ties to the government. As Souchou Yao puts it, the "social and economic realities" of life in Singapore ensured that European prejudice toward the Chinese was "highly selective" and dependent on class.102 In Singapore, the "respectable" master was of necessity defined by class rather than based on race.

Furthermore, labelling the Chinese "corrupting masters" would have been a risky strategy in the context of exploitation colonialism. Considering the symbolic significance of domestic mastery, to exclude the Chinese from the status of respectable mastery was to exclude them from coloniser status. This would allocate the British a long-term moral responsibility for the colony, a situation that was not consistent with their colonial objectives. As the acting secretary of the Straits Settlements, Hayes Marriott, explained in 1921, it was the Chinese, Indians and Malays who "look upon this Settlement as their home" and who would "form a permanent population" in Singapore.103 The cultural sensitivity displayed by the British in Singapore was in their own best interests, providing a means to maintain colonial stability and business as usual.

In contrast to the display of cultural sensitivity of British colonists in Singapore, in Darwin many middle class white colonists who wrote to the press or recorded their memoirs, as well as government representatives, depicted the Chinese as corrupters. In Singapore it was in the government's interest to avoid alienating the Chinese population; in Darwin the interests of the Commonwealth administration were exactly the opposite. By the 1920s, the Chinese residents of Darwin were, for the most part, born in Australia. In the context of white Australia, the government needed a means to deny these Australian-born residents a legitimate place in the north. One solution lay in condemning Chinese domestic mastery and elevating white domestic mastery. Thus, chief protector of Aboriginals, Baldwin Spencer, enforced the ban on Chinese employment of Aboriginal people with enthusiasm, claiming in 1912 that, because of the Chinese love of opium and alcohol: "Nothing is more patent than the rapid degeneration of the native in contact with the Chinese."104 
White residents often reproduced the justifications of the government verbatim. In the $1920 \mathrm{~s}$, a letter to the editor of Darwin's Northern Standard claimed that in some parts of the Northern Territory "Chinese are allowed to work" Aboriginal people and as a result, "they have an open go at opium." The notion that all Chinese were corrupters and exploiters was also fuelled by reports of the mui tsai system and other forms of slavery operating within China that were published in the same newspaper.105 Unlike in Singapore, the corrupting Chinese master was always portrayed as a male (probably because of the lower proportion of Chinese women in Darwin compared with Singapore) and as a potential sexual threat to Aboriginal women.106

There is evidence that Chinese men exploited Aboriginal people. Opium smoking was prevalent among the Chinese community and oral history accounts suggest that Chinese men supplied the drug to Aboriginal people. There are also accounts of violent abuse.107 It is likely that Chinese men used Aboriginal women for sex in conditions that were exploitative. However, white employers were also known for supplying their Aboriginal workers with alcohol and opium and for sexually exploiting Aboriginal women. As Ann McGrath has shown, Chinese and white men sought formal and informal marriages with Aboriginal women and had sexual relationships with them that were exploitive or mutually beneficial.108 By depicting Chinese men as corrupters, white colonists obscured their own abuse, exploitation and dispossession of Aboriginal people. Blaming the Chinese for the abuse of Aboriginal Australians allowed white colonists to depict themselves as benevolent protectors and to present the colonial venture as a moral one.

Not all the white residents of Darwin accepted whole-heartedly the discourse of the corrupting Chinese master. In 1911, a group of 7 prominent Chinese businessmen acknowledged "a debt of gratitude to our European fellow townsmen" for their expressions of sympathy in regards to their treatment by the Commonwealth government.109 S.J. Mitchell, the acting administrator of the Northern Territory at the time of the Commonwealth takeover, argued against the ban on Chinese employers, maintaining that some Chinese employers treated their Aboriginal employees well. When a second petition was sent to Spencer in 1912 to protest the prohibition placed on Chinese employment of Aboriginal people, twenty-seven prominent white residents signed it. Challenging the view of the Chinese as corrupting and degrading masters, their solicitor argued that they were "as fit as the average European to employ natives."110 The government, however, refused to reconsider the ban. In stark contrast to Singapore, in Darwin notions of race and fears of miscegenation meant that even respectable middle class Chinese were seen as unworthy of domestic help in the form of Aboriginal servants. This was the antithesis of white Australia and would signal the doom of the colonial venture.

The discourse of the corrupting Chinese master was not only mobilised with conviction in Darwin, it was contrasted with its "natural" opposite-what Haskins describes as the transcolonial image of "the kindly mistress."111 In contrast to the experience of deprivation that Aboriginal people had supposedly experienced in Chinese homes (and would again if the legislation was changed), it was claimed mixed-descent girls working in white homes under white women experienced maternal care. J.W. Bleakley, protector of Aborigines in Queensland, captured the general view when he suggested that by working as domestic servants, Aboriginal girls obtained "a good home" in which the white mistress would provide "motherly care and domestic training."112 
The image of the bad Chinese master and the good white mistress is observable in Jeanie Gunn's 1908 memoir of her year in the Northern Territory. According to Gunn, Cheon, her Chinese cook, suggested that she "buy a little Chinese maiden to wait on the missus." In response, Gunn informed Cheon of "the abolition of slavery throughout the Empire." Even so, he argued for "buying the treasure and saying nothing about it to the Governor."113 Instead, Gunn acquired an Aboriginal girl, Rosy. In the case of Rosy, there is no suggestion of slavery. This account shows the reach of the antimui tsai campaign, but the emphasis on Chinese slavery is significant for another reason. John Fitzgerald has argued that claims of Chinese slavery were used to justify the exclusion of the Chinese from a supposedly egalitarian white Australian nation.114 Gunn's account is a good example of the attempted exclusion of the Chinese from the white nation based on inherent Chinese corruption and white morality.

In Darwin, government rhetoric emphasised that the kindly white mistress should be like a mother to her Aboriginal ward. However, in a context in which interracial intimacy was in some instances illegal and considered immoral, the white population of Darwin was more likely to treat Aboriginal servants as "distant companions" than as daughters. This was, after all, common practice in other European tropical colonies such as British Rhodesia and Singapore.115 Some white women did genuinely care for the mixed-descent girls working in their homes. However, in white homes in Darwin (as in Chinese homes in Singapore), the potential for abuse was fuelled by notions of familial relationships and ownership.

Many of the Aboriginal women who worked as domestic servants describe their experience as one of slavery.116 As with mui tsai, mixed-descent girls in service were vulnerable to sexual and physical abuse by their employers.117 These girls, like the mui tsai, were subject to the will and power of their masters and had little chance for redress.118 Even in cases where Aboriginal girls were "well looked after" and "never worked," they did not necessarily feel part of the family. Thus, Dolly Bonson remembers her experience living in a white home in Darwin in the 1930s, explaining she was there to "look after them two little girls" rather than being reared as a daughter herself.119

In Darwin, the dual discourse of the corrupting Chinese master and the kindly white mistress was mobilised despite the evidence that the system of Aboriginal apprenticeships involved systematic abuse. The use of this discourse was essential to manage fears and anxieties about white colonial legitimacy and the future of the north. The intention of incorporating Darwin into the white nation ensured that the Commonwealth government, and a significant number of white residents, could not risk displaying cultural sensitivity when it came to the Chinese community. The Chinese needed to be resolutely excluded from coloniser status. In a context in which the Chinese community was Australian-born and permanently settled, this discourse asserted that they did not belong and would never belong in a white egalitarian nation, while the presence of white people was righteous and moral.

\section{Conclusion}

The transcolonial child rescue movement of the interwar years had a significant impact on Chinese homes in Darwin and Singapore. In Darwin, governmental intervention into Chinese homes ensured that the entire Chinese community lost their ability to employ Aboriginal servants. At the same time, Aboriginal girls were removed from their families and communities and forced to work in white homes. In Darwin, most government representatives and many white middle class commentators 
mobilised the discourse of the corrupting Chinese master with conviction, contrasting this image with that of the kindly white mistress. The contention that the experience of Aboriginal servants in Chinese homes had been one of deprivation, while in white homes mixed-descent girls experienced kindly maternal care, was upheld despite the evidence that the conditions of employment in white homes rested on ideas of ownership that in some cases fostered abuse.

In Singapore, the child rescue platform resulted in some mui tsai being removed from conditions of forced domestic labour. Here only those households that opted to obey the easily defied laws lost their ability to employ servants. Those middle and upper class Chinese households who could afford to turned to waged domestic servants, such as amahs, for their domestic service needs. While the government in Singapore used the rhetoric of child rescue to silence international critics, there was a hesitation to condemn Chinese employers despite the evidence of systemic abuse of mui tsai. The colonial government and its agents were careful to point out that, though the mui tsai system was somewhat repugnant, only a minority of Chinese employers were corrupting masters.

While the rhetorical manifestations and practical effects of child rescue seem entirely different, in both Darwin and Singapore the child rescue movement allowed colonial administrators to combat humanitarian criticism while continuing to pursue their distinct colonial objectives. The different responses to Chinese employers of servants in Darwin and Singapore need to be considered in light of the colonial significance of domestic mastery. Domestic mastery was a symbol and an expression of colonial mastery. Thus, the ability of the Chinese to employ servants based on their class position potentially conferred to them coloniser status.

The hesitation with which the discourse of the corrupting Chinese master was used in Singapore, demonstrates that the colonial mastery of the elite Chinese was relatively acceptable. The British were unwilling to condemn the wealthy merchants or Straits Chinese with whom the administration had close ties and relied on for colonial stability. Furthermore, the British were not prepared to accept the inevitable consequences of condemning Chinese mastery. To condemn Chinese mastery inferred that the British were the only worthy and moral masters. Such an assertion would make the British entirely responsible for the colony and would tie them to it forever. In the context of exploitation colonialism, this was unacceptable.

In contrast to Singapore, in Darwin any threat to the idea that coloniser status was determined by whiteness brought into question the entire colonial project. The discourse of the corrupting Chinese master, particularly when contrasted with the kindly white mistress, demonstrated that though the Chinese could afford to employ servants (and had done so the past), the way they exercised this power excluded them from coloniser status. Here, the unflinching adherence to the idea that the Chinese were corrupt masters was a means to resolve anxiety about the small but significant numbers of Australian-born, permanent Chinese settlers and the concern that Darwin, a multiethnic colony on the edge of Asia, would never be part of the white settler nation. In Singapore, anxiety about colonial stability and the future of the colony was evoked by the mobilisation of the discourse of the corrupting Chinese master. In Darwin, colonial stability and national destiny rested on its unquestioned assertion.

A study of Chinese domestic affairs in Darwin and Singapore during the interwar years illustrates the value of analysing non-European homes in order to understand the transcolonial politics of intimacy. Debate within white colonial society about who was an appropriate domestic master, anxiety about 
what went on inside Chinese homes and government intervention into these homes illustrates that colonial power was just as invested in Chinese homes as it was in white homes. Moreover, analysing the politics of intimacy in Chinese homes illustrates the degree to which the status of coloniser was ambiguous, contested and dependent on colonial context. In the case of exploitation colonialism in Singapore, class power was central to coloniser status while in Darwin, race distinctions were far more important in determining who was a settler and a coloniser.

For correspondence: Claire.Lowrie@newcastle.edu.au.

Notes

1. The author would like to thank the anonymous reviewer of the article as well as Lisa Featherstone, Julia Martinez and Victoria Haskins for their excellent feedback on this article. I would also like to acknowledge the Research Institute for Social Inclusion and Wellbeing at the University of Newcastle, the University of Wollongong and the Northern Territory Archives Service whose generous support enabled me to undertake the research on which this paper is based.

2. Sylvia Van Kirk, Many Tender Ties: Women in fur trade society in western Canada, 1670-1870 (Winnipeg: Watson and Dwyer, 1980); Ann Laura Stoler, Carnal Knowledge and Imperial Power: Race and the intimate in colonial rule (Berkeley: University of California Press, 2002), 6, 8, 123, 129, 133, 216; Elsbeth Locher-Scholten, "So Close and Yet So Far: The ambivalence of Dutch colonial rhetoric on Javanese servants in Indonesia, 1900-1942," in Domesticating the Empire: Race, gender, and family life in French and Dutch colonialism, eds. Julia Clancy-Smith and Frances Gouda (Charlottesville: University Press of Virginia, 1998), 140; Jeremy Martens, "Settler Homes, Manhood and 'Houseboys:' An analysis of Natal's rape scare of 1886," Journal of Southern African Studies 28: 2 (2002): 394; Victoria Haskins, "On the Doorstep: Aboriginal domestic service as a 'contact zone'," Australian Feminist Studies 16: 34 (2001): 18.

3. Ann Laura Stoler, "Tense and Tender Ties: The politics of comparison in North American history and (post) colonial studies," Journal of American History 88: 3 (2001): 831.

4. Victoria Haskins, One Bright Spot (Houndmills: Palgrave, 2005), 5-6.

5. Victoria Haskins and Margaret Jacobs eds., "Special Issue: The Home and Colonization," Frontiers: A Journal of Women Studies 28: 1\&2 (2007).

6. Locher-Scholten, "So Close Yet So Far," 136; Peter Hey, The Rise of the Indian Natal Elite (Pietermaritzburg: Natal Witness, 1962); Lai Ah Eng, Peasants, Proletarians and Prostitutes (Singapore: Institute of Southeast Asian Studies, 1986), 45-55; Christine Chin, In Service and Servitude (New York: Columbia University Press, 1998), 69-47; Nicole Constable, Maid to Order in Hong Kong (Ithaca: Cornell University Press, 1997), 42-48.

7. Swapna Banerjee, Men, Women and Domestics: Articulating middle-class identity in Colonial Bengal, (Oxford: Oxford University Press, 2004), 31.

8. Stoler, "Tense and Tender Ties," 456.

9. Penny Edwards, "On Home Ground: Settling land and domesticating difference in the 'non-settler' colonies of Burma and Cambodia," Journal of Colonialism and Colonial History 4:3 (2003); Deana 
Heath, "Comparative Colonialism, Moral Censorship and Governmentality," in Decentering Empire, eds. Durba Ghosh and Dane Kennedy (New Delhi: Orient Longman, 2006), 213, 229.

10. Stoler, Carnal Knowledge and Imperial Power, 13.

11. Kam Louie, "Chinese and Japanese Global Masculine Identities," in Asian Masculinities, eds. Kam Louie and Morris Low (London: Routledge Curzon, 2003), 10.

12. Edwin Lee, The British as Rulers Governing Multiracial Singapore, 1867-1914 (Singapore: Singapore University Press, 1991), 91-92, 288; Carl Trocki, Opium and Empire: Chinese society in Colonial Singapore, 1800-1910 (Ithaca: Cornell University Press, 1990), 34.

13. Penny Edwards and Shen Yuanfang, "Something More: Towards reconfiguring Australian history," in Lost in the Whitewash, eds. Penny Edwards and Shen Yuanfang (Canberra: Humanities Research Centre, 2003), 6; Peta Stephenson, The Outsiders Within: Telling Australia's IndigenousAsian story (Sydney: University of New South Wales Press, 2007), 68.

14. Douglas Lockwood, The Front Door: Darwin, 1869-1969 (Adelaide: Rigby Limited, 1968), 81.

15. C.M. Turnbull, A History of Singapore, 1819 - 1975 (Kuala Lumpur: Oxford University Press, 1977), 88-9.

16. Rhoades Murphey, "On the Evolution of the Port City," in Brides of the Sea: Port cities of Asia from the 16th-20th centuries, ed. Frank Broeze (Honolulu: University of Hawaii Press, 1989), 225; Mary Louise Pratt, Imperial Eyes: Travel writing and transculturation (New York: Routledge, 2007), 7.

17. "Burns, Philip and Company Steam Ship Monotoro will Sail for Singapore on Monday 27th of January," Northern Territory Times, January 30, 1913; "Steamer Sails: Burns Philip Line," Straits Times, January 9, 1911.

18. Diana Giese, Beyond Chinatown: Changing perspectives on the top end Chinese experience (Canberra: National Library of Australia, 1995), 43.

19. David Carment, Looking at Darwin's Past (Darwin: North Australia Research Unit, 1996), 6: Henry Reynolds, North of Capricorn: The untold story of Australia's north (Crows Nest: Allen and Unwin, 2003); 109.

20. National Archives of Australia (hereafter NAA), "Census figures for Darwin, 1911," A1/15 $11 / 16191$.

21. Glenice Yee, Through Chinese Eyes: The Chinese experience in the Northern Territory, 1874-2004 (Parap: Glenice Yee, 2006), 38; F.X. Alcorta, Darwin Rebellion, 1911-1919 (Darwin: University Planning Authority, Darwin, 1984), xii.

22. Catriona Elder, "Immigration History," in Australia's History, eds. Martyn Lyons and Penny Russell (Sydney: University of New South Wales Press, 2005), 107.

23. Julia Martinez, "Ethnic Policy and Practice in Darwin," in Mixed Relations: Asian-Aboriginal contact in North Australia, ed. Regina Ganter (Crawley: University of Western Australia Press, 2006), $123,125$. 
24. NAA, "Census figures for Darwin, 1911"

25. Hayes Marriott, "The People's of Singapore: Inhabitants and population," in One Hundred Years of Singapore, eds. Walter Makepeace, Gilbert Brooke and Roland Bradell (Singapore: Oxford University Press, 1991), 359-360.

26. Edwin Lee, "Community, Family, and Household," in A History of Singapore, eds. Ernest Chew and Edwin Lee (Singapore: Oxford University Press, 1991), 247.

27. Yen Ching-Hwang, "Class Structure and Social Mobility," Modern Asian Studies 21:3 (1987): 418.

28. C.F. Yong, Chinese Leadership and Power in Colonial Singapore (Singapore: Times Academic Press, 1992), xv, xvi.

29. In using the term overseas Chinese (huaqiao) it is not my intention to infer homogeneity. The term overseas Chinese is favored in this article as it was the term used in Singapore at the time. Gungwu Wang, "Greater China and the Chinese Overseas," The China Quarterly 136 (1993): 926, 939; Leo Suryadinata, "Ethnic Chinese in Southeast Asia: Overseas Chinese, Chinese Overseas or Southeast Asians," in Ethnic Chinese as Southeast Asians, ed. Leo Suryadinata (Singapore: Institute of Southeast Asian Studies, 1997), 2, 8, 10.

30. Lee, The British as Rulers Governing Multiracial Singapore, 91-92, 288; Trocki, Opium and Empire, 34.

31. C.B. Buckley, An Anecdotal History of Old Times in Singapore (Kuala Lumpur: University of Malaya Press, 1969), 357; Julia Martinez and Claire Lowrie, "Colonial Constructions of Masculinity: Transforming Aboriginal Australian men into 'houseboys,'" Gender and History 21: 2 (2009): 308; Warwick Anderson, The Cultivation of Whiteness (Carlton: Melbourne University Press, 2005), 4-5.

32. Martens, "Settler Homes, Manhood and 'Houseboys,'" 394; Stoler, Carnal Knowledge and Imperial Power, 133; Locher-Scholten, "So Close, Yet So Far," 135; Alison Blunt, "Imperial Geographies of Home: British domesticity in India, 1886-1925," Transactions of the Institute of British Geographers 24:4 (1999): 430.

33. Martinez and Lowrie, "Colonial Constructions of Masculinity," 308.

34. John Cameron, Our Tropical Possessions in Malayan India (London: Smith, Elder and Co., 1865), 289.

35. "Life in Darwin: Mrs Urquhart's Experiences," Northern Standard, March 26, 1926.

36. B.W. Higman, Domestic Service in Australia (Carlton: Melbourne University Press, 2002), 45.

37. National Archives of Singapore (hereafter NAS), "Transcript of Interview with Low Cheng Gin," 000287/ 23 (1983), 53.

38. Lai, Peasants, Proletarians and Prostitutes, 77, 24, 46, 47. 
39. NAA, "Chinese storekeepers to Justice Mitchell, Government Resident, 22 March 1911," A1/15 1912/10547; Northern Territory Archives Service (hereafter NTAS), "Employment of Abo. Girl by Chinese H.S. Lee," NTRS829, 8666.

40. Timothy Jones, The Chinese in the Northern Territory (Darwin: Charles Darwin University Press, 2005), 1.

41. Lockwood, The Front Door, 81.

42. Howard Malcolm, Travels in South-Eastern Asia (Boston: Gould, Kendall and Lincoln, 1839), 92.

43. C.D Mackellar, Scented Isles \& Coral Gardens (London: John Murray, 1912), 275.

44. Shurlee Swain, "Centre and Periphery in British Child Rescue Discourse," in Rethinking Colonial Histories, eds. Penny Edmonds and Samuel Furphy (Melbourne: The History Department, University of Melbourne, 2006), 156.

45. Stoler, "Tense and Tender Ties," 852, 850, 851; Penny Edwards, "Mixed Metaphors: Other mothers, dangerous daughters and the rhetoric of child removal in Burma, Australia and Indochina," Balayi, 6 (2004): 42, 47; Swain, "Centre and Periphery in British Child Rescue Discourse," 157; Margaret Jolly, "Other Mothers: Maternal 'insouciance' and depopulation debate in Fiji and Vanuatu, 1890-1930," in Maternities and Modernities, eds. Kalpana Ram and Margaret Jolly (Cambridge: Cambridge University Press, 1998), 4.

46. Maria Jaschok and Suzanne Miers, eds., Women and Chinese Patriarchy:Submission servitude and escape (Hong Kong: Hong Kong University Press, 1994); Lai, Peasants, Proletarians and Prostitutes, 45-55; Chin, In Service and Servitude, 69-47; Constable, Maid to Order, 42-48.

47. Edith Picton-Turbervill, "Minority Report," in Mui Tsai in Hong Kong and Malaya, eds. W.W. Woods and C.A. Willis (London: His Majesty's Stationery Office, 1937), 215.

48. Lai, Peasants, Proletarians and Prostitutes, 47.

49. "Hong Kong Slavery: Reuter telegram," Straits Times, December 3, 1920; Susan Pederson, "The Maternalist Movement in British Colonial Policy: The controversy over child slavery in Hong Kong, 1917-1941," Past and Present 171 (2001): 163.

50. "Enclosure 3 in No. 13," Extracts from Report of Proceedings in Hong Kong Legislative Council (London: His Majesty's Stationery Office, 1922), 30; Meng Cheng Lin, "Chinese Women," Straits Chinese Magazine 2 (1898): 158.

51. NAS, "Transcript of Interview with Seow Guat Beng," 0001048/20 (1989), 22; Irene Cheng, Clara Ho Tung: A Hong Kong Lady (Hong Kong: Chinese University Press, 1980), 59.

52. Philip Holden, Modern Subjects/Colonial Texts (Greensboro: ELT Press, 2000), 73; Eric Tagliacozzo, Secret Trades, Porous Borders (New Haven: Yale University Press, 2005), 230.

53. "The Problem of the Mui Tsai: Some Suggestions for Solution, 'System is a blot,"' South China Morning Post, 15 May 1930, 9. 
54. Victor Purcell, The Chinese in Malaya (London: Oxford University Press, 1948), 82.

55. Lai, Peasants, Proletarians and Prostitutes, 51.

56. Jolly, "Other mothers, dangerous daughters and the rhetoric of child removal in Burma, Australia and Indochina," 4.

57. Janet Lim, Sold for Silver: An autobiography of a girl sold into slavery in Southeast Asia (Singapore: Monsoon Books, 2004), 45.

58. Tan Beng Hui, "'Protecting' Women: Legislation and the Regulation of Women's Sexuality in Colonial Malaya," Gender, Technology and Development 7 (2003): 21.

59. Report on the Administration of the Mui Tsai Legislation in Malaya in 1937 and of other action taken for the Protection of Girls (London: Colonial Office, 1937), 5.

60. W.W. Woods and C.A. Willis, eds., Mui Tsai in Hong Kong and Malaya: Report of Commission (London: Colonial Office, 1937); Picton-Turbervill, "Minority Report," 214; Lai, Peasants, Proletarians and Prostitutes, 53.

61. Lai, Peasants, Proletarians and Prostitutes, 77.

62. Lucy Lum, The Thorn of Lion City: A memoir (London: Fourth Estate, 2007), 49.

63. Lai, Peasants, Proletarians and Prostitutes, 50-53.

64. Purcell, The Chinese in Malaya, 182.

65. Victoria Haskins, "Domestic Service and Frontier Feminism," Frontiers 28:1-2 (2007): 127.

66. "The Problem of the Mui Tsai," South China Morning Post, 15 May 1930.

67. Martinez, "Ethnic Policy and Practice in Darwin," 123.

68. Tony Austin, Never Trust a Government Man (Darwin: Northern Territory University Press, 1997), 3.

69. Tony Austin, "'A Chance to be Decent': Northern Territory 'half-caste' girls in service in South Australia," Labour History 60 (1990), 53.

70. Alan Powell, Far Country: A short history of the Northern Territory (Carlton: Melbourne University Press, 1996), 161.

71. Ann McGrath, "Consent, Marriage and Colonialism," Journal of Colonialism and Colonial History, $6: 3$ (2005).

72. Haskins, "Domestic Service and Frontier Feminism," 126.

73. Austin, "'A Chance to be Decent,"' 52; Martinez, "Ethnic Policy and Practice in Darwin," 128.

74. Stephenson, The Outsiders Within, 81. 
75. Stoler, Carnal Knowledge and Imperial Power, 131-32.

76. NTAS, "Employment of Abo. Girl by Chinese H.S. Lee."

77. Edwards, "Mixed Metaphors," 51

78. NAA, "Chinese storekeepers to Justice Mitchell, Commonwealth Administrator,' 22 March 1911," A1/158 1912/10547.

79. NAA, "Chinese storekeepers to Josiah Thomas, Minister for External Affairs, 7 May 1912," A1/158 1912/10547.

80. Hilda Jarman Muir, Very Big Journey: My life as I remember it (Canberra: Aboriginal Studies Press, 2004), 10.

81. Haskins, "Domestic Service and Frontier Feminism," 125.

82. Stoler, "Tense and Tender Ties," 856.

83. Rowena MacDonald, Between Two Worlds (Alice Springs: IAD Press, 1995), 27.

84. Tony Austin, "Training for Assimilation: Cecil Cook and the 'Half-Caste' Apprentice Regulations," Melbourne Studies in Education 29 (1987/88): 131-132.

85. Haskins, "Domestic Service and Frontier Feminism," 127.

86. Robert Mann, "Aboriginal Child Removal," in Genocide and Settler Society:Frontier violence and the Stolen Generations, ed. Dirk Moses (New York: Berghahn, 2004), 217-242.

87. Mary Montogomery Bennett, The Australian Aboriginal as a Human Being (London: Alston Rivers, 1930), 97.

88. "The Black Man's Burden," Sunday Express, 3 June 1934.

89. Haskins, "Domestic Service and Frontier Feminism," 131.

90. Fiona Paisley, Loving Protection: Australian feminism and Aboriginal women's rights (Carlton: Melbourne University Press, 2000), 91; Edwards, "Mixed Metaphors," 42

91. Hugh Clifford, Malayan Monochromes (New York: E P Dutton and Company, 1913), 133.

92. Pederson, "The Maternalist Movement," 182, 183; Sarah Paddle, "The Limits of Sympathy: International feminists and the Chinese 'slave girl' campaigns of the 1920s and 1930s," Journal of Colonialism and Colonial History 4:3 (2003).

93. Picton-Turbervill, "Minority Report," 233.

94. "A Chinese Girl-Slave," Straits Times, July 14, 1899; "Cruelty to Mui Tsai: Story of a callous mistress, a shocking case," South China Morning Post, 9 May 1930.

95. Purcell, The Chinese in Malaya, 181, 179. 
96. NAS, "Transcript of Interview with Lucia Bach," 0000184/25 (1982), 94.

97. Picton-Turbervill, "Minority Report," 214, 231.

98. Lim, Sold for Silver, 38.

99. Locher-Scholten, "So Close Yet So Far," 152, 133, 138, 140, 144.

100. Picton-Turbervill, "Minority Report," 233.

101. Paddle, "The Limits of Sympathy."

102. Souchou Yao, "Social Virtues as Cultural Text: Colonial desire and the Chinese in 19th-century Singapore," in Reading Culture: Textual practices in Singapore, eds. Phylliss G. L. Chew and Anneliese Kramer-Dahl (Singapore: Times Academic Press, 1999), 103.

103. Marriott, "The Peoples of Singapore," 360, 353.

104. Annual Report of the Northern Territory (Darwin: Commonwealth Government, 1912), 48.

105. "Starving Blacks," Northern Standard, 19 April 1925; "Child Factory Slaves: Industrial horrors in China," Northern Standard, 11 May 1925.

106. In Darwin in 1911, Chinese women made up twenty-one per cent of the Chinese population. In Singapore in the same year, they made up twenty-five per cent of the Chinese population and by 1931 they made up fifty per cent. NAA, "Census figures for Darwin, 1911"; Sharon Lee, "Female Immigrants and Labor in Colonial Malaya," International Migration Review 232 (1989): 314-16.

107. "Darwin Police Court," Northern Territory Times, 30 November 1918; NTAS, "Transcript of Interview with Beatrice Frith," NTRS266, TS213, 28; "The Discouragement of White Labor: Cruelty to Natives," Northern Standard, 25 April 1922.

108. Stephenson, The Outsiders Within, 62-63; McGrath, "Consent, Marriage and Colonialism."

109. NAA, "Chinese storekeepers to Justice Mitchell."

110. Martinez, "Ethnic Policy," 157.

111. Haskins, One Bright Spot, 7.

112. J.W. Bleakley, The Aborigines of Australia (Brisbane: Jacaranda, 1961), 168.

113. Jeanie Gunn, We of the Never-Never (London: Hutchinson \& Co, 1908), 97.

114. John Fitzgerald, Big White Lie: Chinese Australians in white Australia (Sydney: University of New South Wales Press, 2007), 7-9.

115. Karen Hansen, Distant Companions (Ithaca: Cornell University Press, 1989), 305; Kenneth Gaw, Superior Servants (Singapore: Oxford University Press, 1988), 104.

116. Shirleene Robinson, "'We do not want one who is too old': Aboriginal child domestic servants in late 19th and early 20th century Queensland," Aboriginal History 27 (2003): 169-72. 
117. NTAS, "Transcript of Interview with Vai Stanton," NTRS266, TS783 (1990/91), p. 6.

118. For a direct comparison of the experiences of the mui tsai and Aboriginal servant girls see:

Claire Lowrie, "Domestic 'slaves' and the rhetoric of 'protection' in Darwin and Singapore during the 1920s and 1930s," Journal of the Oriental Society of Australia 39-40: 2 (2008): 334-356.

119. NTAS, "Transcript of Interview with Dolly Bonson," NTRS266, TS429/2 (1982), t. 1, p. 9. 